\title{
The essential health reform in Chile; a reflection on the 1952 process
}

\author{
Francisco Mardones-Restat, MC, (1) Antonio Carlos de Azevedo, PhD.(2)
}

\begin{abstract}
De Azevedo AC, Mardones-Restat F. The essential health reform in Chile; a reflection on the 1952 process. Salud Publica Mex 2006;48:504-5 II.
\end{abstract}

\begin{abstract}
The authors claim that the critical health reform in Chilean history was the establishment of the National Health Service (NHS) in 1952. The development of modern Chilean health care since the end of the 19th century is discussed both in terms of the prevailing health situation and the subsequent evolution of institutions and policies, with an emphasis on the social and political conditions that led to the creation of the NHS in 1952. From this analysis and from a comparison of infant mortality rates among Latin American countries during the same period, the authors infer that the 1952 health reform was the social and political benchmark that allowed Chile to exhibit the relatively favorable health situation it still enjoys. Using Cavanaugh's scheme, it is clear that the "first-generation reform" was the reform imposed by the military regime in the early 1980s, which aimed to change the orientation of the health system. Similarly, the "second-generation reform" was that implemented by the democratic administrations of the early 1990s to reverse the harm done by their military predecessors. The rapid aging of the population and the advent of new technologies pose a challenge to the insurance system's coverage capacity and threaten the sustainability of all health systems. The implementation of universal, comprehensive, collective health systems, managed under the most integrated authority political conditions will allow, is emphasized as an appropriate solution for developed and developing countries alike.
\end{abstract}

Key words: Chile; infant mortality; health policy; health systems reform

\author{
De Azevedo AC, Mardones-Restat F. \\ La reforma de salud esencial en Chile: \\ una reflexión sobre el proceso de 1952.
}

Salud Publica Mex 2006;48:504-5 I I.

\section{Resumen}

Los autores sostienen que la reforma de salud crítica en la historia chilena consistió en el establecimiento del Servicio Nacional de Salud (SNS) en 1952. Se discute el desarrollo de la atención a la salud moderna desde fines del siglo XIX, en términos de la situación de salud imperante y de la evolución de las instituciones y políticas que le siguieron, haciendo énfasis en las condiciones sociales que llevaron a la creación del SNS en 1952. Al analizar y comparar las tasas de mortalidad infantil en países latinoamericanos para el mismo periodo, los autores infieren que la reforma de salud de 1952 fue el hito que permitió a Chile alcanzar la situación relativamente favorable que aún ostenta. Usando el esquema de Cavanaugh, queda claro que la "reforma de primera generación" fue la impuesta por el régimen militar a principios de los ochenta, la cual se proponía reorientar el sistema de salud. De manera similar, la "reforma de segunda generación" fue la implementada por los gobiernos democráticos de principios de los noventa, que trataron de reparar el daño hecho por sus predecesores militares. El envejecimiento acelerado de la población, así como el surgimiento de nuevas tecnologías constituyen un reto para la capacidad de cobertura del sistema de seguros y amenazan la sostenibilidad de todo sistema de salud. Se hace énfasis en que una solución apropiada tanto para países en desarrollo como desarrollados, es la implementación de sistemas de salud universales, integrales y colectivos, administrados por la autoridad más integrada que sea permitida por las condiciones políticas.

Palabras clave: Chile; mortalidad infantil; política de salud; reforma en atención de la salud

(I) Universidad de Santiago de Chile, Chile.

(2) Universidad de Sao Paulo, Brasil.

Received on: June 2,2006 - Accepted on: July 20, 2006

Address reprint requests to: Antonio Carlos de Azevedo. Universidad de Sao Paulo Brasil.

Prala de Botafogo 74,Apto. 901. 22-250-040 Río de Janeiro, Brasil.

E-mail: a-c-azevedo@uol.com.br 
T $\mathrm{n}$ light of the recent 50th anniversary of the Chilean National Health Service (NHS), the authors' review of recent literature on health reforms suggests the utility of a commentary on the social roots of this important phenomenon and on the profound changes that Chile began to undergo in the early 1950s. The authors represent two different points of view: Mardones, a direct participant at the start of the health reform process, was able to follow its evolution for four decades as a manager, teacher, and researcher; Azevedo, a public health researcher who lived in Chile as an international consultant on health services development from 1993 to 1999, had the advantage of a first-hand, yet externally-oriented, view. It is hoped that the combination of these two perspectives will contribute to a discussion of this exciting process and the measures necessary to assure its future. In sum, the challenge is to evaluate the development of the Chilean health system since 1952 under the conceptual framework proposed by Cavanaugh. ${ }^{1}$

Some authors identify three milestones in the development of the Chilean health system during the 20th century: ${ }^{1}$ the 1952 Reform, which was defined by the creation of the NHS; ${ }^{2}$ a second movement beginning in the 1980s, during the military regime, marked by the privatization of a substantial portion of the system; ${ }^{3}$ the 1990's Reform, following democratization, designed to correct problems introduced by the military regime through such measures as the restoration of the public health network and the regulation of the activities of private health insurers (ISAPRES). ${ }^{2}$

\section{The preconditions}

The first thing to consider is that, while the Chilean health setting was similar to that in other Latin American countries at the beginning of the XX century, the sociopolitical conditions that allowed the creation of the NHS were quite different. Official reports from 1885 reveal that the mortality rate was higher than the birth rate; in other words, the country showed signs of demographic involution. ${ }^{3} \mathrm{~A}$ series of epidemics and the global economic crisis of the closing decades of the 19th century led to stagnation in the mining and grain export industries, bringing multitudes of the unemployed to the cities. The atmosphere of intense need and urban poverty triggered social initiatives -called "Mutual Aid Societies" ("Sociedades de Socorro Mutuo")- to respond to health problems. Moreover, a number of charitable organizations began to merge progressively into a national coordinating institution called the "Beneficencia Pública". At the end of the 1870s, this entity consisted of just 12 groups in Santiago; ${ }^{3}$ by the 1920 s, it numbered $115 .{ }^{4}$ In the initial years of the 20th century, organizations called "Milkdrops" (Gotas de Leche) emerged, whose purpose was to improve the nutrition of poor infants and children in periurban areas. Paralleling the Mutual Aid Societies, in 1901 the Milkdrops began to be coordinated by a public authority called the National Children's Protection Agency (Patronato Nacional de la Infancia, created by Dr. Luis Calvo Mackenna). ${ }^{5}$ It is clear from these examples that Chile, like many other Latin American countries, based its health care system on not-for-profit facilities, originating in and managed through public charities. This is similar to the volunteer hospital model that prevailed in the United States during the first half of the 20th century. The fundamental difference is that, beginning in the closing decades of the previous century, Chilean initiatives were coordinated by an agency with a strong state presence, called the National Public Welfare Commission (Comisión de la Beneficiencia Pública), created in $1877 .^{3}$ This is helpful in understanding the support base for the future NHS. Another institution with a role in Chile's social response to health problems was the Chilean Medical Society, created in $1873 .{ }^{3}$ In contrast to the state of affairs in other South American countries, the Chilean Medical Society had a deep-rooted social focus from its beginning, and its presence and support were essential to the creation of the NHS. Furthermore, as early as 1833, the Chilean Constitution recognized the concept of "Public Health" ("Salubridad Pública"). ${ }^{5}$

The Chilean Health Code was published in 1918, while the Pan-American version dates from 1924. The Workers' Compulsory Insurance Law (Seguro Obrero Obligatorio) was implemented in 1924; other South American countries developed similar legal instruments within the same decade. Unlike similar agencies in neighboring countries, the Workers' Compulsory Insurance Fund (Caja del Seguro Obrero Obligatorio) incorporated existing facilities, thus avoiding duplication. In 1924, the Ministry of Hygiene, Health Care, and Social Security (Ministerio de Higiene, Asistencia y Previsión) was created, a visionary institution when compared to its counterparts in neighboring countries.The Preventive Medicine Law of 1938 laid further groundwork towards a favorable environment for the emergence of the future NHS. The founding of the National Office for Protection of Children and Adolescents (Dirección de Protección de la Infancia y Adolescencia - PROTINFA) in 1942 permitted to consolidate into a single national agency all activities involving immunization, food supplementation, support for abandoned children, and other problems affecting this age group. Moreover, this entity assumed a coordinating role in ongoing public and private efforts. The National Medical Service for Civil Servants (Servicio Médico Nacional de los Empleados-SERMENA) was 
created in 1942. Although this institution never became part of the NHS, the two entities coordinated their activities. As in other countries of the region, the first preventive health centers were created in 1945 with the support of the Rockefeller Foundation (Quinta Normal in Santiago, Cerro Barón in Valparaíso, and a similar facility in San Felipe). The establishment of the School of Public Health at the University of Chile's Medical School led to the training of the professionals who would manage the NHS in the following decade. ${ }^{5}$

\section{The political context of the 1952 reform}

From the 1920s on, a series of important social changes transformed the national political landscape. After World War I and the Soviet Revolution, a new workers' union movement began to play a significant role, competing with the traditional humanist ideologies of existing workers' groups. At the same time, two highly socially sensitive forces were strengthened: a progressively institutionalized medical class and the military forces, which, from this point on, would have an important role in Chile's social and political development. In the early 1930s, the Chilean Medical Association (AMECH) emerged, partially in response to a public health crisis: in 1933, an infant mortality of 232 deaths per 1000 live births was recorded, together with 1188 malaria cases in the northern region of the country. AMECH would play a progressively greater role in the identification of and public debate over these and other health problems prevalent in the low-income population. ${ }^{3}$ The interaction of these forces increasingly contributed to what Chilean social scientists call the "Benefactor" or "Provider State" (Estado Benefactor o Estado Proveedor). These changes influenced the social and political life of the country and formed a cohesive background for changes from this point forward. Indeed, it was physician Eduardo Cruz-Coke, a Christian socialist, who in 1938 proposed the economic foundations for the protection of workers' health. ${ }^{8}$ In his paper, he insisted on the economic rationale for the social protection of workers, proposing the Preventive Medicine Law and what was then called "Targeted Medicine" (Medicina Dirigida), a state initiative to manage health challenges.

In the 25 years preceding the creation of the Ministry of Health, the following bases for the National Health System can be recognized:

1. the Workers' Protection Fund (Caja de Seguro Obrero, created in 1924 by Law 4054 through the initiative of Dr. Exequiel Gonzalez Cortes );
2. the establishment of the Public Welfare (Dr. Sotero del Río, 1935);

3. the creation of the National Council for Nutrition (Consejo Nacional de Alimentación, Dr. CruzCoke, 1937);

4. from the same source, the Maternal and Child Law;

5. the Preventive Medicine Law;

6. the NHS law project (Salvador Allende, 1939);

7. the PROTINFA (National Agency for the Protection of Children and Adolescents) (Dr. Morales Beltrami);

8. the creation of the School of Public Health, (Dr. Hernán Romero, 1942);

9. the foundation of the Chilean Medical Association (Colegio Medico de Chile, Dr. Rene Garcia Valenzuela, 1948).

There was also important external support, such as that offered by UNICEF for the creation of a powdered milk industry and penicillin production, the immunization of newborns against $\mathrm{TB}$, and the fortification of flour with iron and B-complex vitamins during Dr. Jorge Mardones' administration at the Ministry of Health. In 1939, Minister of Health Dr. Salvador Allende published "The Chilean Social Reality", a conceptual milestone for the future NHS. ${ }^{3}$

\section{Essential features of the first Chilean reform in 1952}

Minister of Health Dr. Salvador Allende G. first proposed the creation of the NHS in 1939, during the administration of President Pedro Aguirre Cerda, in a text expressing the logic, need for, and urgency of the reform under consideration. Notwithstanding, the project was stalled for 10 years in Parliament. There are many explanations for this delay; the need for increases in social security contributions and tax hikes are often cited. The Chillán earthquake of 1939, which caused more than 20000 deaths and spread destruction over three provinces, offered the opportunity to coordinate public facilities and organizations with remarkable results in terms of perceived effectiveness and efficiency. This enormous catastrophe brought the country together and led to the creation of an Agency for Reconstruction and Aid (Corporación de la Reconstrucción y Auxilio) and a government proposal, approved by Congress, to create other national institutions that considerably boosted the country's development-for example the Corporation for Promoting Production (Corporación de Fomento de la Producción- CORFO). The 1952 Health Reform was not 
the least of these social policy initiatives. A basic feature of the NHS, created by Law 10383 (August 8, 1952), was the presence of a General Director appointed by the President and confirmed by the Senate. Structurally, the NHS consisted of a General Directorate and two Sub-Directorates, one executive and one regulatory. One of its chief innovations was the creation of a National Health Council (NHC), which joined a number of health executives and leaders in a decisionmaking body. Among participants in the NHC were the Ministry of Health, the Ministry of Social Security, the General Director of the NHS, the Director of Social Security, two academics, two appointed representatives of the Medical Society, two representatives of business organizations (Instituciones Patronales), two representatives of workers' organizations, two members of the Senate and two of the Lower House of Congress. ${ }^{5}$ The composition of its managing board reinforces the conclusion that the NHS achieved the feat of joining the most dynamic forces of the productive and public health sectors under State leadership.

The first General Director of the NHS was Dr. Hernán Urzua, with Drs. B. Juricic and Abraham Horwitz $^{*}$ as the first executive and regulatory directors, respectively. A second board (the "Consejo Técnico"), comprised of the heads of the Departments of Health Protection, Health Promotion, and Rehabilitation, was assigned the extensive administrative task of drawing up technical norms for application at every level of the service's structure. Members of this technical board included the 13 Zone Directors and invited experts, including some of the most prominent scholars from schools of health sciences around the country. These technical experts may be credited with the debate over and ultimate acceptance of a number of important changes introduced by the NHS in health practices as a consequence of the unification of public health services. One of the functions of the managing board was to establish standard fees for procedures provided by the system (a function that today is exercised by the National Health Fund - FONASA).

The first concerns of the NHS were the control of vaccine-preventable diseases, under the leadership of Dr. Conrado Ristori, and the provision of milk, with the initial support of UNICEF and Caritas-Chile. These activities were expanded after a 1957 law earmarked 5\%

\footnotetext{
* The authors consider it worthwhile to mention that, aside from his important contribution to the success of the NHS, for 12 years Horwitz was the Director of PAHO, which celebrated its 100th anniversary in 2002, at the same time as the 50th anniversary of the Chilean NHS.
}

of the Worker's Family Fund (Asignación Familiar Obrera) for the NHS. At the same time, the Medical School of the University of Chile began the regionalization of pediatrics education and practice under Professor J. Meneghello. Among his other contributions to the practical management of child medical issues, Professor Meneghello introduced rehydration by gastroclysis in 1955 as an effective treatment for diarrhea, at the time a common health problem. This and other advances were implemented through innovative mechanisms for knowledge diffusion, including the Foundation for Continuous Education in Pediatrics (FUDOC o Fundación de Docencia Continua en Pediatría), a scientific journal and classic textbook that has gone through many editions and is still important today. ${ }^{10}$

\section{Outcomes of the 1952 reform}

\section{Human resources in the development of the NHS}

In order to broaden medical education at the Medical School of the University of Chile, a committee was formed, chaired by Professor Ramón Valdivieso, who later became Minister of Health under President Eduardo Frei. This committee advocated the joint education of physicians with nurses, midwives, nutritionists, psychologists, medical technologists, physiatrists, and members of other specialties. The medical school and the NHS joined efforts to encourage the creation of schools all over the country in an attempt to fill the gaps identified by this committee. The School of Public Health provided the administrative personnel to run the system. In 1957 the Rural Practitioner's Program (Médico General de Zona) was implemented. This mechanism, which still survives today, directed attention to underserved populations, primarily in rural areas, using economic incentives, grants for further specialization, and the promise of careers in public service.

During the Valdivieso ministry, laws on occupational safety (Law \#16754) and workers' medical care (Law \#16888) attempted to redistribute human resources and thus expand health coverage. The General Council approved a physician career plan, providing economic incentives to professionals beginning their activities at the institution. A 40 to $60 \%$ increase over the basic wage was provided as a hardship allowance for service in remote locations, weighted by the length of service. Three years was the minimum commitment required to take advantage of this allowance, with an extension, in some cases, to five, with the first long-term incentive granted at the end of the third year. Physicians were also entitled upon return to a specialization grant in addition to the basic wage, resulting in what is today the chief financing mechanism for medical residencies in Chile. 
The NHS began a cooperative program with medical schools to improve and diversify the profile and quality of their careers. This action reinforced initiatives like the training of professional midwives at the University of Chile Medical School from 1834 on, a policy fostered by Dr. Lorenzo Sazie, the first dean, which is considered to be an important factor in the considerable advances in maternal and child health. Encouraged by the NHS, a second school for midwives was created at Valparaíso in the Deformes Hospital under Prof. Anquelen, who was its director from 1955 on. In the 1960s, new schools were created in Valparaíso, Concepción, Valdivia, and Santiago. Similar sequences of events occurred in the schools of nursing and nutrition, as well as those of other health professions.

\section{The national program for birth regulation}

In 1966, the NHS upgraded its maternal and child care program with an educational component, counseling and birth control services. It had been observed that the system's clientele had adopted abortion performed by nonprofessionals as the primary form of birth control, with the consequent high morbidity and mortality among pregnant women. To convince those opposed to abortion policies, a thorough epidemiologic study showed that $20 \%$ of fertile women were at risk for a nonmedical abortion, with potentially considerable damage to their health and even loss of life. The NHS shared its findings with a number of groups that played leadership roles in the intellectual and social life of the country. The reassuring atmosphere of these discussions allowed the Director of NHS to develop a policy on abortion, which was subsequently supported by an editorial in the Medical Society Review (Revista de la Sociedad Médica de Chile) in 1966.8,9

This and other public health issues received the advice and support of medical school faculty and other qualified professionals, thus providing the political clout necessary for appropriate decision-making.

Many authors ascribe Chile's favorable health indicators-compared with those of other Latin American countries- to the basic health services coverage provided over four decades, which was a result of the 1952 Reform. Figure 1 reinforces this perception, by comparing the trend in Chilean infant mortality with that for eight other countries of the Hemisphere. During this period, the reduction in Chilean infant mortality surpassed the trends of all other countries, representing one of the best situations in the Region by the 1980s.

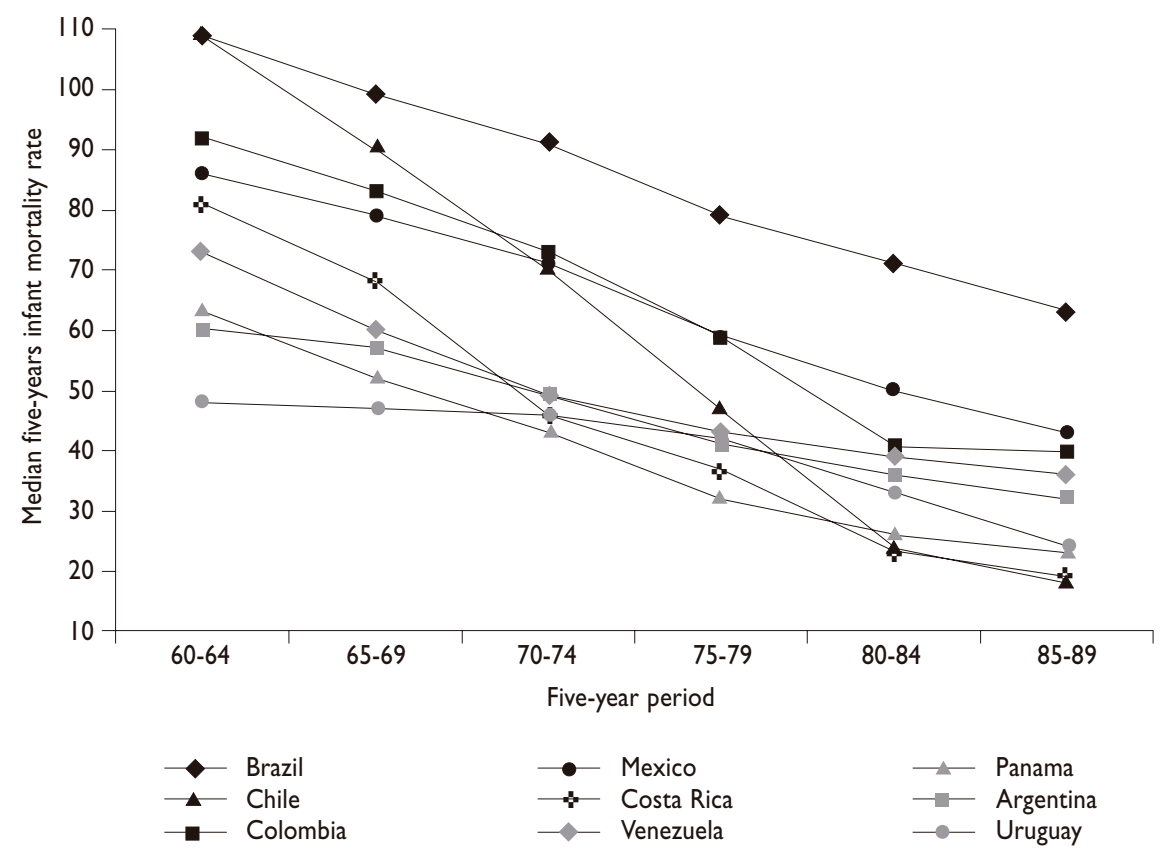

Fuente: OPS/OMS. Publicación Científica No. 556.

Elab. F Mardones Restat. Dirección de Dirección de Graduados FACIMED USACH., $200 \mathrm{I}$

Figure I. Infant mortality trends in Latin America (1960-I989) 


\section{The late evolution of the reform process}

The decision of the military government to privatize health care financing and delivery, with the support of the international economic system, helped to define the evolution of the NHS from 1973 on. The rationale for this decision was to shrink the state apparatus and lighten the tax burden, a prescription widely offered to developing countries at the time. This resulted in the creation of private health insurers (ISAPRES) and subsequently, the mandatory municipalization of primary care and abandonment of the maintenance of public hospitals. The authors will not delve more deeply into this process, as it is extensively discussed elsewhere.

During the 1980s, there was a considerable deterioration in health care, resulting not only from the prior health policy but also from the global economic recession, which hit the national economy hard and affected the financing of social programs. The upgrading of public health facilities and equipment was severely limited. At the same time, the earning capacity of health professionals fell by nearly $50 \%$. The legitimate partial redress of these reversals by the 1990s reform was unfairly interpreted as a loss in service productivity, i.e. the same services for greater remuneration of human resources.

Health care for the poorest sectors was seriously affected in the 1980s by the interruption of the Rural Practitioner's Program (Medico General de Zona), which was by then widely perceived as effective. As mentioned earlier, this mechanism was responsible for the initiation of a large proportion of health professionals in NHS practices. It is worth noting that by the 1990s, the program for physicians and dentists had not only resumed but was also broadened to include nurses. Indeed, during the military regime, the integration of the health sector was severely damaged. By decree, and without social or political debate even within the Ministries of Health or Education, primary care was decentralized to the municipalities and the Ministry of Health forced to pay for these services via a system called FAPEN (fee-for-services). In an attempt to correct abuses stemming from this authoritarian measure, a per capita system was introduced in 1994, linking payment to the number of families enrolled at each outlying health unit. ${ }^{10}$ Equity was nonetheless a collateral casualty of this process, since wealthier municipalities were able to offer a wider range of services than the poorer ones.

The municipalization of primary care

Some authors have called this government decision of the $1980 \mathrm{~s}^{11}$ "a wound to the health sector" because it undermined the integrity of health care for the population. Unlike their counterparts in other countries in the Region, Chile's municipalities were neither prepared nor willing to assume the new functions.

In the 1990s, the new democratic government attempted to gradually reintegrate the health system, beginning with a UNICEF-supported study (in which one of the authors participated [F. Mardones et al. 1990-94]) on the vulnerability of children in Chilean communities. This study marked the start of a recovery process, financed by the Ministry of Health, in 60 municipal health units; it was followed by the creation of Primary Care Emergency Units (SAPUS), which were credited with improving primary care through a considerable extension of the time devoted to each patient.

Technical expertise was another casualty of the forced municipalization of the 1980s, as the management of primary health services was transferred from trained professionals to politically appointed mayors. It would be unfair not to mention the exceptions, where the new management of a few particular health units discharged their duties with honor, dedication and effectiveness. Another serious side effect was the detachment of primary care units from the more specialized facilities under the Ministry of Health. Moreover, the interest of medical schools in teaching primary health care declined considerably as the relationship with municipal facilities grew weaker. With democratization, the municipalities markedly improved their management skills and reliability.

From the 1990s on, a credit from the World Bank supported the renovation of some hospitals and the replacement of others with new facilities, as in the case of San Jose Hospital in Santiago, as well as the construction and outfitting of a series of primary and secondary care units. These investments represented a valuable boost for the primary health care network. ${ }^{12}$

Reduced admissions to the schools of medicine, nursing, and midwifery in the 1970s and 1980s resulted in a critical shortage of these types of professionals. To some extent, migration from other Latin American countries alleviated this problem. The long-term solution may involve the creation of new schools for health professionals at both the public and private sectors.

\section{Was the 1952 Chilean reform a first-generation reform?}

In a recent paper on Latin American health reform processes, Karen Cavanaugh proposes the classification of these sociopolitical phenomena into two categories: first- and second-generation reforms. First-generation reforms would be those based on state structural ad- 
justment processes involving the control of inflation and the fiscal deficit, the liberalization of trade, the privatization of public enterprises, and the reduction or elimination of price imbalances. Second-generation reforms would be those based on increasing the regulatory role of the State, establishing legal frameworks, and improving state managerial capacity. In Cavanaugh's terms, second-generation reforms would seek to build social and organizational capital. This author's conceptual framework takes for granted that development is a function of participation, ownership, and the setting of internal priorities. $^{1}$

An examination of the 1952 reform in Chile shows that none of the defining conditions for a first-generation reform was met. Figure 2 summarizes the characteristics of such a reform according to Cavanaugh. Our analysis indicates that, in general, as in the majority of Latin American and Caribbean countries, the countries in question have historically weak social policies, a weak public sector, and an active but uncoordinated private sector. The latter may be for-profit or not-forprofit, and in many countries is a mixture of both. Firstgeneration reform consists of the privatization of financing or service delivery, or more commonly, both.
This results in an increase in the available health services, while maintaining or even heightening the disorganization of the sector, resulting in a high degree of inequity and inefficiency. The goal of second-generation reforms, according to Cavanaugh, is to correct these problems, since the establishment of a legal and regulatory framework will alleviate the disorder almost inevitably engendered by the first process. The end result of this sequence of reforms is a private health sector regulated to some degree by the State and with a clear separation of functions.

Figure 3 describes the development of the health sector in Chile. Prior to 1952, the country had a series of well-developed public policies, a strong public sector, and a private sector where on the one hand, the for-profit component was quite weak, and on the other, the not-for-profit component had been co-opted by the reform process and was already part of a public oversight institution (Beneficencia Pública). These factors permitted the construction of an integrated and integrating National Health Service, which was instrumental in attaining the health indicators seen in figure 1 in subsequent decades. One can also see from figure 3 that, according to Cavanaugh's conceptualization, the

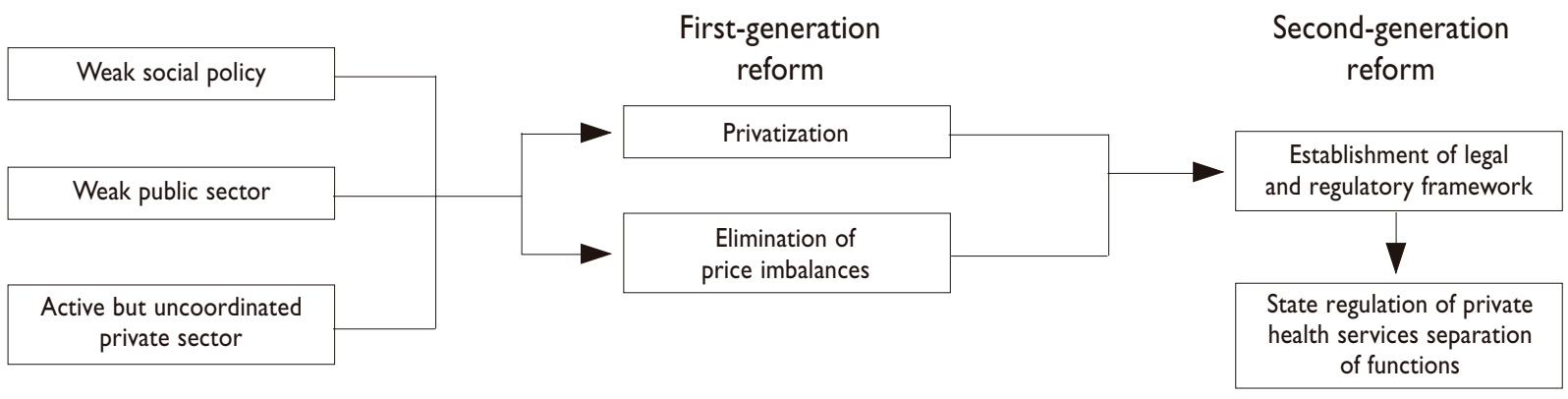

Figure 2.The "Cavanaugh Scheme" for health systems reform in Latin America

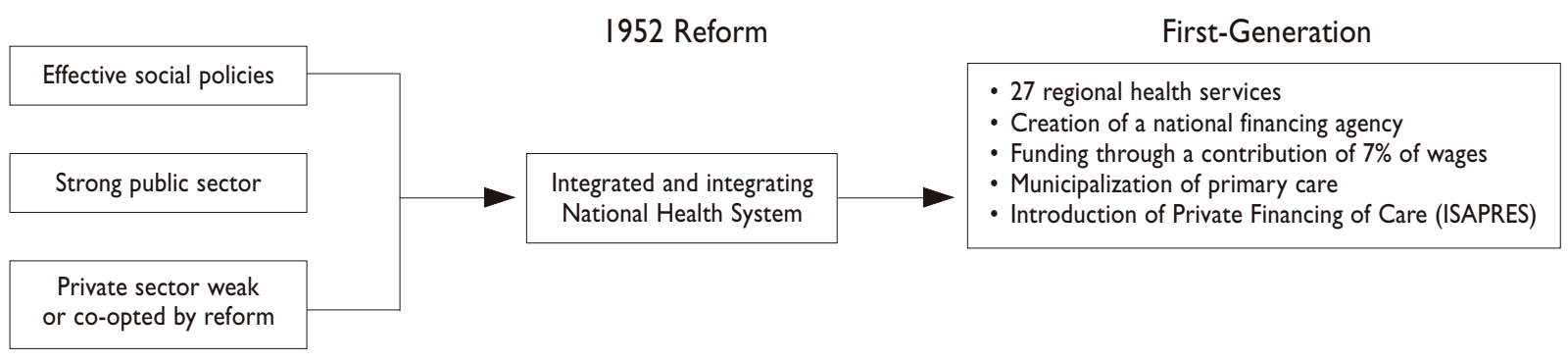

Figure 3.The Chilean reforms 
first-generation reform was the one that took place in 1980. This reform explicitly sought to privatize the existing system as part of a state policy aimed at reducing public expenditures, a strategy that has since been insistently advocated by the development banks for Chile and other countries. This process was complemented with the following policies: decentralization of health services and the creation of regional health services; a change in the financing model from a fiscally-based system to one based on workers' contributions; the creation of FONASA; the municipalization of primary care; and the creation of private financiers of health care, the ISAPRES (Instituciones de Salud Previsional or Private Health Insurers). These measures seem to fit what Cavanaugh describes as first-generation reform. The consequences of these changes are shown in figure 4 . Even if one sets aside the political environment that led to the reform, it is impossible not to recognize its results: a two-decade setback in health investment, the abandonment of public infrastructure, the creation of an unregulated private health financing system, and the development of a private health services delivery network, concentrated mostly in major urban areas.

\section{Towards the future}

Worldwide changes over the past few decades, including the rapid aging of the population and the intensive introduction of new technologies, demonstrate the need to return to the idea of comprehensive, unified health systems. Indeed, the arrival of genomics and proteomics point to the possibility of identifying with extraordinary precision the risk of disease and disability in growing segments of the population -that is, they allow for the identification of a high-risk population,

First-generation Reform
\begin{tabular}{|l|l|}
\hline - 27 Regional health services & - Decrease in health \\
- Creation of a national & investment \\
financing angency & - Creation of the ISAPRES \\
- Funding through a & Regulatory Agency (I99I) \\
contribution of 7\% of wages & - Mandatory \\
- Municipalization of primary & Municipalization of \\
care & primary care \\
- Intoduction of Private & Increase in number of \\
Financing of Care (ISAPRES) & private careproviders \\
\hline
\end{tabular}

Figure 4.Outcomes of the first generation Reform IN CHILE a reality that constitutes a real threat to the insurability of a considerable portion of humanity. ${ }^{13}$ Even authors associated with extremely unregulated health systems like that of the United States recognize the need for a more unified social response to these challenges. This was brought to light in the last interview given to Health Affairs by Avedis Donabedian, one of the most prestigious authors in quality management in health care. ${ }^{14}$ In this interview, Donabedian comments on the future need for the United States to consider a unified health system, clearly similar to the one that emerged from the ideals of the Chilean Health Reform of 1952.

\section{References}

I. Cavanaugh K, Zeballos JL, Savedoff B. A roundtable discussion on international cooperation in health reform in the Americas. Rev Panam Salud Publica/Pan Am J Public Health 2000;8(I/2): I40-I46.

2.Azevedo AC. La Provisión de Servicios de Salud en Chile: aspectos históricos, dilemas y perspectivas. Rev Saúde Pública (S. Paulo) 1988;32(2): 192-199.

3. Illanes MA. En nombre del pueblo, del Estado y de la Ciencia Historia Social de la Salud Pública. Chile 1880 / 1973. Santiago, Chile: Colectivo de Atención Primaria, 1993.

4. Horwitz CN et al. Salud y Estado en Chile. Antecedentes de la Creación del Servicio Nacional de Salud en Chile. El Contexto Político y Social Chileno. Santiago, Chile: Publicaciones Científicas de la Representación OPS/OMS en Chile, 1995.

5. Horwitz A. El Servicio Nacional de Salud y la Salud Pública Chilena. in Foro La Salud en el Proceso de Desarrollo Chileno. Santiago, Chile, I8 October 1995. (unpublished). Santiago, Chile: PAHO/WHO, 1995. 6. Cruz-Coke E. Economía Preventiva y Economía Dirigida, 1938 apud Illanes, op.cit. Cap. 4. La Intelligentsia Técnica. p. 279.

7. Meneghello J, Rosselot J, Mardones-Restat F. El rol de la Pediatría clínica y social en los avances de la salud y de la familia: Chile 19001995. Rev Pediatr al Día 1995; I I (4):223-232.

8. Rosselot J, Mardones-Restat F. Salud de la Familia y Paternidad Responsable. La experiencia de Chile 1965-1988. Rev Med de Chile 1990; I I8:330-338.

9. Mardones-Restat F. Salud materno infantil; últimos 30 años. Rev Chil de Pediatr 1990;6(5):28I-286.

10. Mardones-Restat F, Conferencia:Análisis del modelo per cápita. Taller Nacional Discusión del Modelo Per Cápita 4-5 October 1995, Santiago, Chile. Organiza MINSAL/FONASA/Comisión Per Cápita. I I. Mardones-Restat F. Una Herida en el Sector Salud. Diario El Mercurio. Santiago. 29/08/1993.

12. Ramirez, M. Centros Diagnóstico Terapéuticos. En: Solimano G, Bergholtz S, eds. Perspectivas de la Red Asistencial en Chile. Chile, Santiago: CORSAPS / OPS-OMS, 1999.

13. Friend S, Stoughton RB. The Magic of Microarrays. Sci Amer 2002;286(2):34-4I.

14. Informando \& Reformando - Avedis Donabedian - Una experiencia directa con la calidad de atención: Boletín Trimestral del NAADIIR/AL Abr/Jun 200I;8:1-2. 